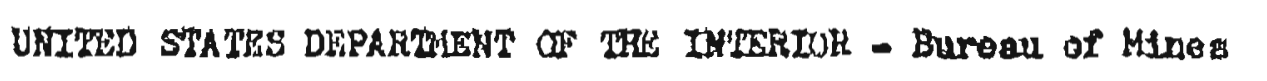

$$
\text { Rogion I - Alaska }
$$

REPORT OF ERAKINATION

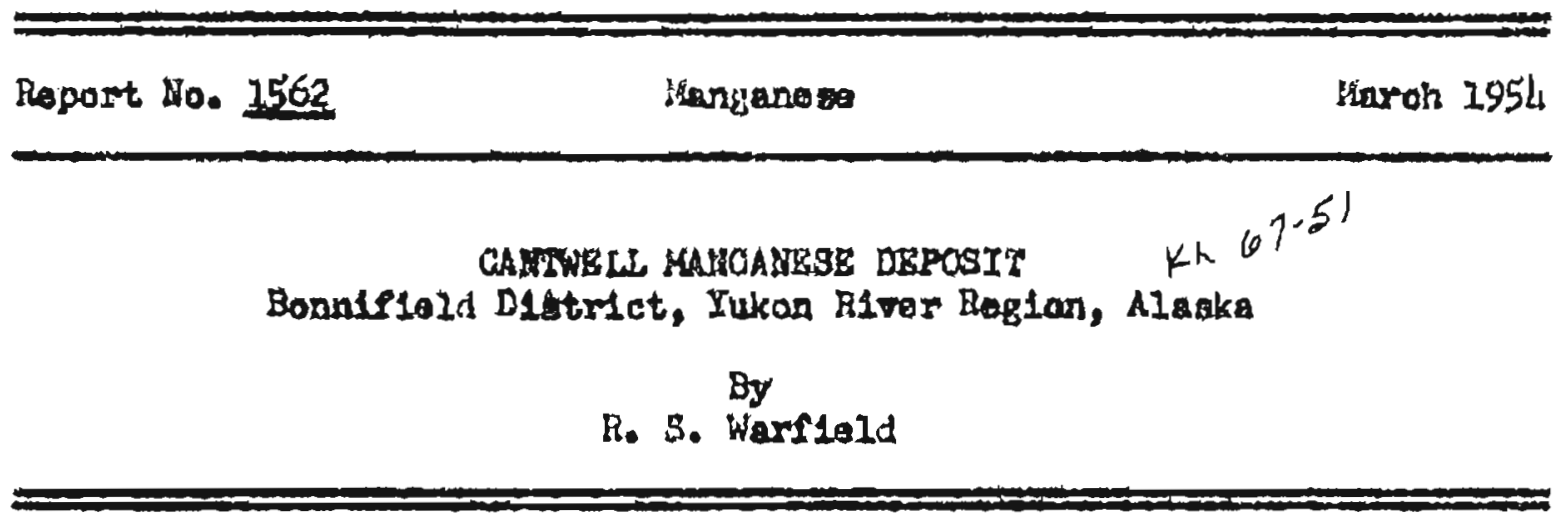

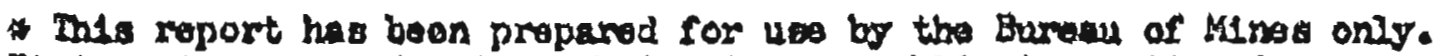
It 19 not racomonded for publication or pubile inapectson for one or more

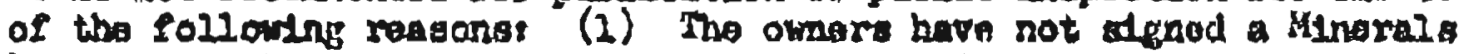
Exploration Agreoneat of given written consant to the publicstion of the roselits of the oxanination. (2) The oxemination was routine and involvod no epoctal or extenalve work by the Bureau of Mines. (3) The results of the exaraination indlated notgetivo or Inalgntficant additions to solentific knowledgo or mineral invontorios. (4) The rapart reccumends a broader Invest1gation whioh may reanl in more work by the Bureau and a subsequent roport for publication. 


\section{Exorination Roport}

CAITW

By

R. S. Warflold/

Contzits

Para

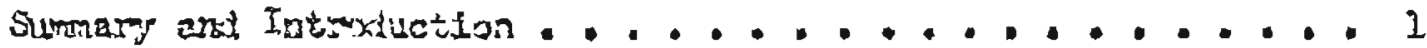

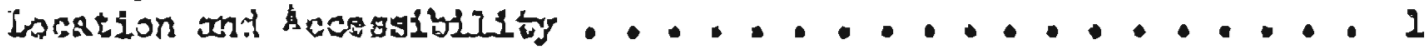

Hiatary and Junarship .................... 2

Descrfotiar of tho Depondt................... 2

(roolors, Oamal .................... 2

The idoptost......................... 3

liork by tivo Bureatu of zlnes ................. 5

Concluglong .......................... 6

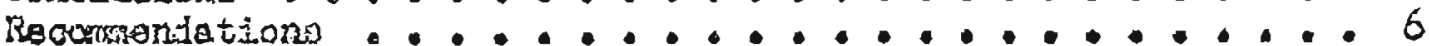

IISUSTRATIOHS

Pollows

Pase

818. I Location jag of Cantwoll Kanganeso Depoatt...... I

Plg. 2 Plar Mas of Cantmali Harganeso Deposit........ 2

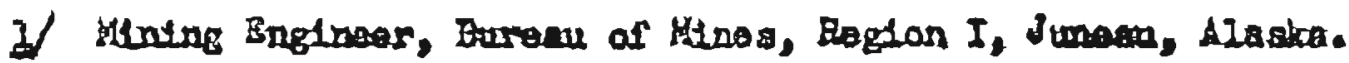


CANTGLLL KHATOANESE

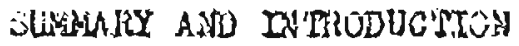

Anglodowar trenchilg and chnnnol eampling was undertakon to

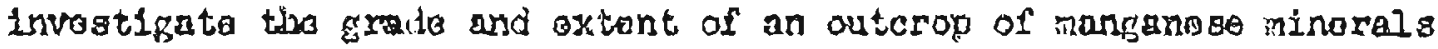
oxposers in a muskeg-covered aroa near LantweIl, Alacka. Lisposive of the outcrop rowalod a noarly vortioal lons approxtinately 15 feot long

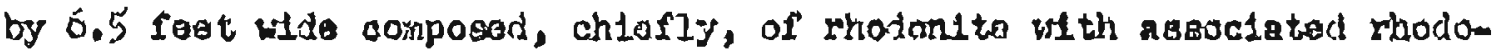
chrosito, bonientto, pyroluaito, and guartz. Approximatoly 2,400 11nogr feot of ancledoper axceration along, and across the olisolfloct shale bods ralled to uncovar addlelonal lorses of rhodonita, although blaok manganess ataln was consplolous and uldely distributed.

Samplas taken durlog a prolintnary axamination $2 /$ indicated that additlonal work on the deposit vas jugtifled. Because of heavy ovarburdon, prinolpally kuskog, angladozor trenching was detominod to bo

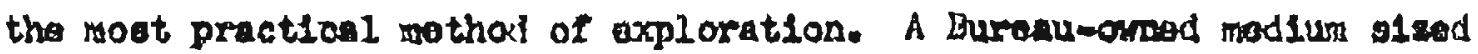

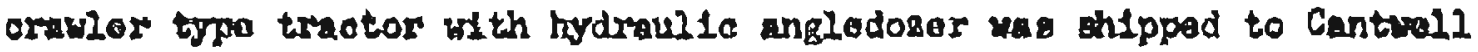
In Auguat 1952 , tronolising was acmplotod Octubar 2, 2952.

LOCATION AND ACCESSIBILIIT

Cantwo 11, Alaska 18 a station on the Alaska rall roadj it 18 ap proxirately 205 nilos north of Anchorage (FLB. 1). The mangano to dapont 10 approxdmately 1/2-m1lo oouthonat of Cantwoll alone tho otoop north bank of the Cantwell Rever approxdratoly 1/2-andio upstram rean

2) Lorain, 8. H., Ragional Dlmotor, Region I, Miraau of Kinog, Iuneas, Alsaka. 


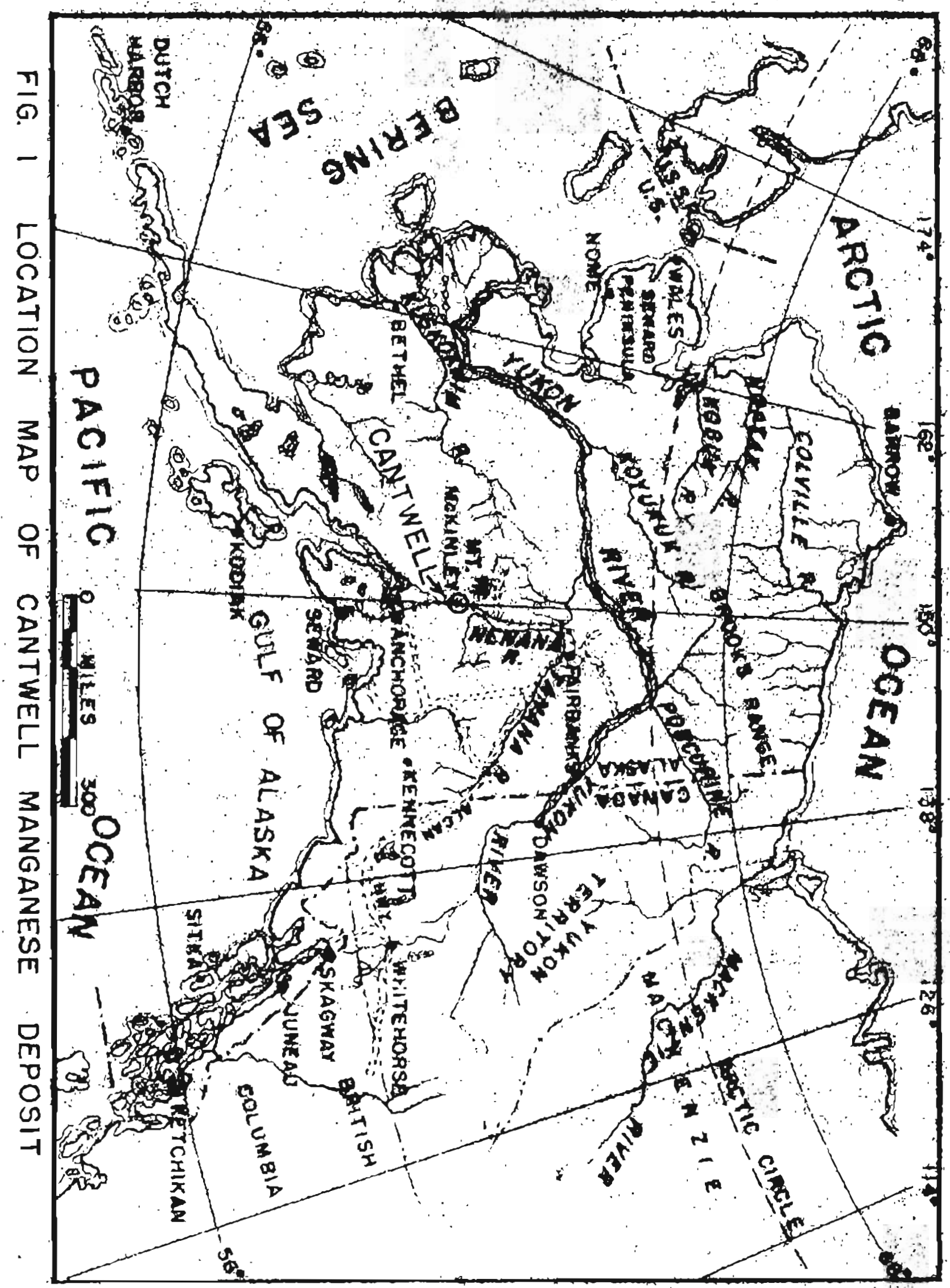


the conflionce of the Cantiosil and Jaok Rivers. Thu dopost is oasily accasalble from Cantwall olthar by troctor or by foot.

HIST'JEY AND GHARTSHIH

Nocording to Cantwell rostidents, the deposit was locatod in 1917 bilt tho location has been permitted to lapso. Latar, H. Buckstrom, who now realdes in cantwoll, opened a sundl oupface cat to exposo frogh, umoathared rhodochrogt.te.

An aren which includes tho deposit was with 3 ram, tomprarily, fron tho public domatn for dafanso purpobes by Publle Land griar óp. liebruary 2, 1951. The whthrawal Lnclutee 119,000 acroe known as the "WLuty Croak Araa".

\section{DH.SGRIPIIUH OF THE DEPOSI'S'}

\section{Quolasthe Oongral}

She ganoral goology of the rogion has boen dosertbod by cappa3/ but no detallad raport of the local geolugy has beon publiahod. Exposure of the bedrook adjacent to the depostt by anfladozer excavation throughoue a distance of about 1,700 feet elong the nortb bank of tho Cantwell Bimr oagtarly and wastarly from the doposit (Fig. 2) rovealed

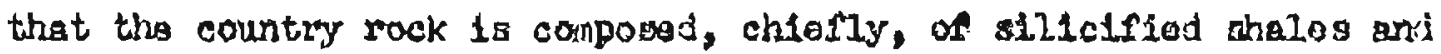
slater. Thase chalos and alatos havo been dosomed to ouch an oxtant that the ortginal bodding asmot be 1dentifled. The strike of the beds

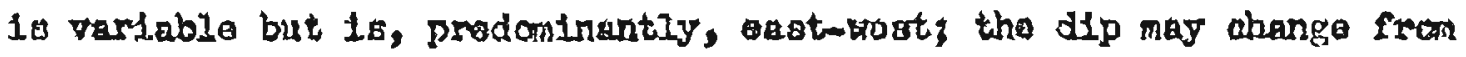
staop northerly to stoop southorly mithin a fow feot. Nany of the bods, 


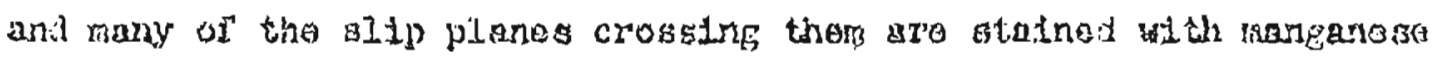

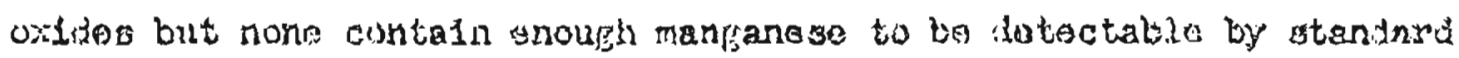
asaly mothods. by projection siron tho natagt axposurgs that, wars mappod by cappeds, and by obtervation of the charactor of the axposat

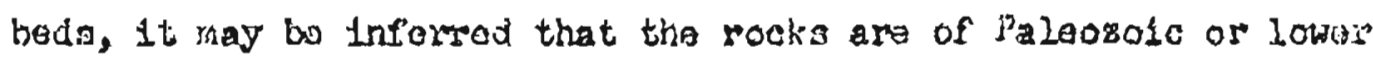
Hosorolc ago. Tho aren that was investlgatad is bout ix milas sointh of a major fault that is approximataly parailol to tho gouthar ody of tho Alaska Ranga.

Accoriling to Capps, the l'aloozolo (or Hosozolo?) Sormatione in

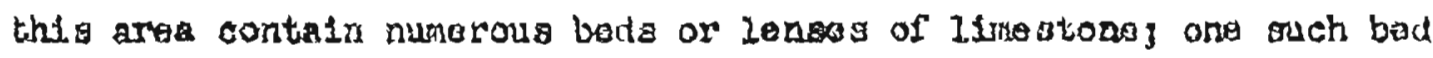
10 oxpozed in a railroad ent about ono milo northenat of Cantwall. A wastward projection of th1 bar would be a short datance north of the

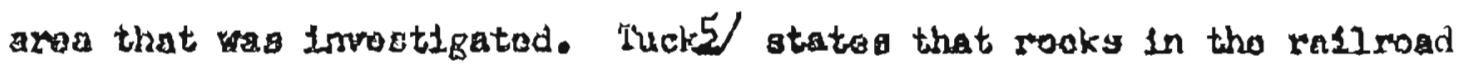
cut about one-half m1le northast of Cantall are stalned by mageneen and that manganose ploat hag been sound on the shoras af andl lakes about throo to four $2110 \mathrm{~g}$ gouthwe of Cantwil. Thoso lakes appear to bo, approximatoly, on the atrike axtersion of tho abovo mentioned 11mestone bado.

Ihe Depoglt

An unpublished roport by Tucke/ atutos that, at the tire of h1s oxalnation (probabif about $1943-(4)$ ), an outorop of otool-gray manganaso

4 hork citod in footnoto 3 (p. 2).

$56 /$ Ruok, Ralph, Extract Pron Hiscellanoous iflnoral Dopooita Alang tyo lagke Rall road undatad roport in toch. Filo, Alnska Radlroed Ralt, Oaologloni Surray. 
o.ride about one foot thick gradod downard into frosh rhosontto and rhodochrostto. The manganese contant af the oxide was 38.5 paxcont.

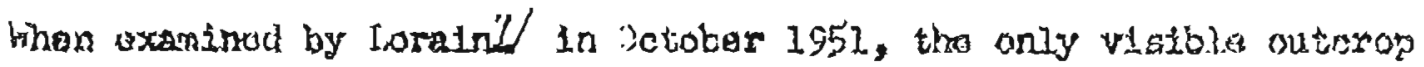
conglated of rasaiva rholochrostto oxposed on the wat alib of an open cut which, at the Iace, was about 3 foet aloop by 2 faet whto. The gouth wall of the rhodochrosito roin, wh the the exception of a namow

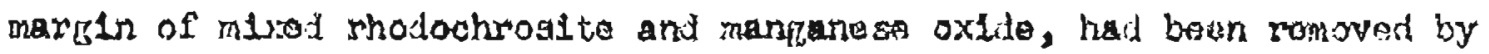
aroaton; tho nomth rall conalotad of highly sllfcifled glato. Potrogaphic reporte by Irwing on samples from the two wallo and frin tho

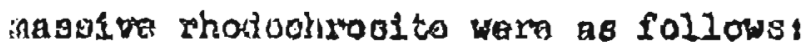

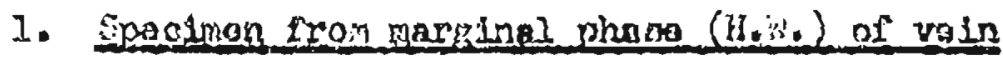

Potrographic doscription "Inds samplo wo found to contain a variaty of rhodochroalte, barite, and bluck manganeso oxido. A magnadan varloty of rhodochrosito is presonty thio varioty contains magraglum in subatitution for mangano up to at least

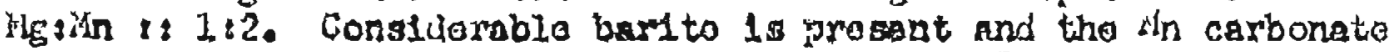
Is altaring to black axida on exponal sirfacos."

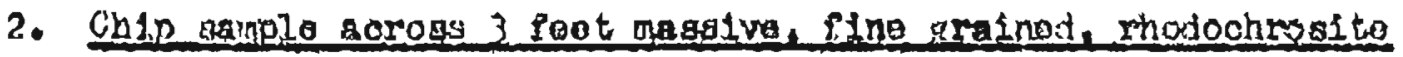

Petragraplife dogortption: "Rhodcchrosita 18 tho matn minaral

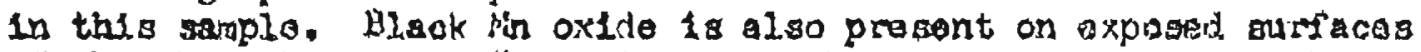
of the rhorlocturagite. Alapnestum and colcian are prosent in sub-

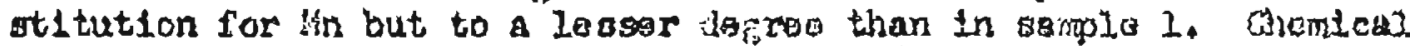
analyalo shows this somple to contain $39.2 \%$ in. Aliso prosent, by

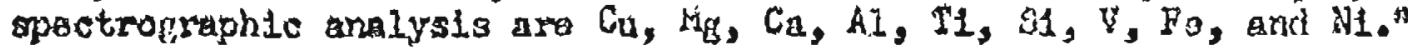

I) Kiork ofted in pootnoto 2 (p. I).

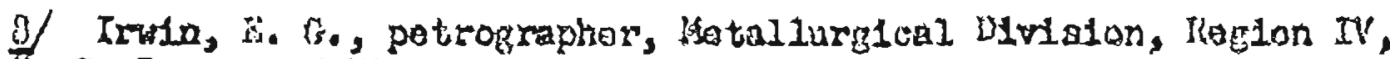

U. S. Bureau of inges. 
3. Wial1 rock of vein (apparantly alata), Lainations atrike i. $-i$ and dip 60 derroes if. Voln apponarg to conforin tor Ianloations of wall rocks

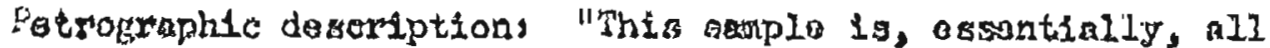
finangrathat quartz itth sarie foldypera. Dark culoration 1a Jue to oxdides of in and lie. Same organic material tis also prosent."

Complete exposure of the outorop by Buroau of kines trenchling rovented that tho deposit consistad of a nearly vertical lons approximately 15 frot long by 6.5 feot wide compoosd, chiofly, of rhodont te but with some assoctated rhodoahrosite quartz, bementito, and mrolusita. the striko of the long axds of the lone wae approxdnintely oastmest, its diroction wh oanformable with the average schlstostty of the wall rocks. Although the bottim of the lons has not beon oxposer after excavating to a dopth of 6 fiet, there was no Indication that 1 ta verteal axds wolld bo natorially longer than 1ta oast-wost axis.

WONK BY 'TEE BUREAU OF' HINGS

In an offort to obtaln a bettar exponura of the deposit and to discover other nangano bearing deponte, tho ofllotifed ahale beds

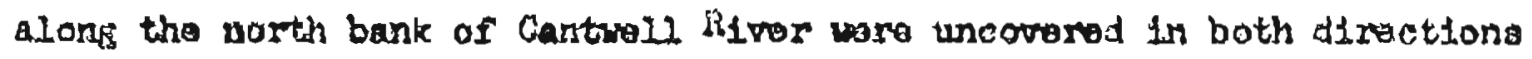
from the rhodochrosite outorop. Approsedmatoly 1,700 fost of rock wBS expored along the steop Cantivell fivor bank.

The area was further explored by throe bulldozer tronchos and by an uncomplatod fourth trench. The tranohas wo out approximutaly acrose the stritke of the westerly projection of thas beds which were moat heavily stalnad by wargarese whero axposed along the rlvor bank. 


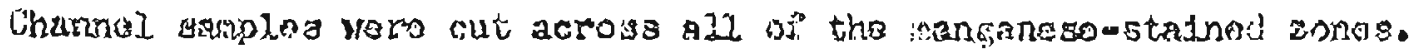

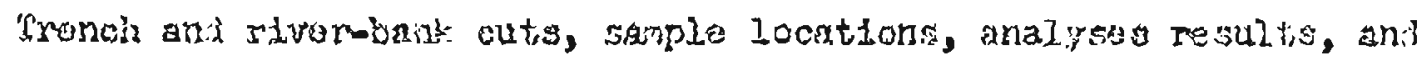

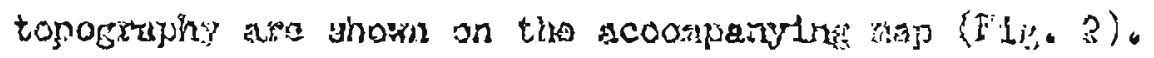

\section{CONOLUSIJW}

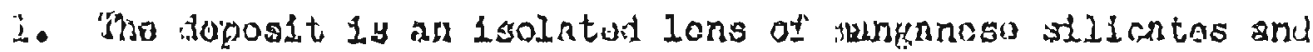
carbonatis which probabliy wa croated by raplacement of a small lins of calcasous aglinentary rocks it has no bonarclal valua.

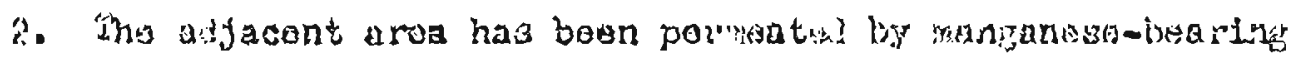
solutione; consoquantly, Larger mangenose dopond a way bo found if

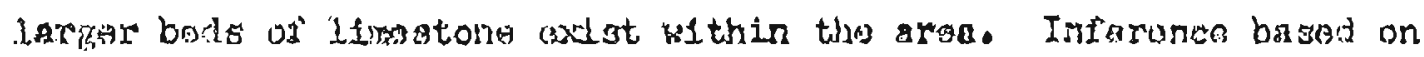

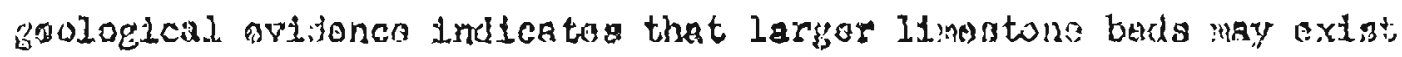
with the arad.

3. The area bistwoan tho doposit and the vilua of contweld sppisems favornble to tha oristence of laryer deposita but tho lom rolinf and deep overburion would rondor exploration diffleklt and exponesus.

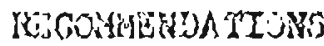

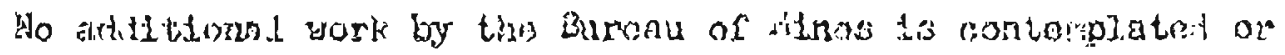
rocomindidad at Gantwoli. 